\title{
Human Immunodeficiency Virus DNA
}

National Cancer Institute

\section{Source}

National Cancer Institute. Human Immunodeficiency Virus DNA. NCI Thesaurus. Code C129662.

DNA that is reverse transcribed from human immunodeficiency virus RNA. 